\title{
Una carta literaria de la Guenizá de El Cairo en judeo-árabe
}

\author{
José Martínez Delgado - Ahmad al Ahmad al Khalaf ** \\ Universidad de Granada
}

Edición, traducción, estudio de los contenidos y análisis lingüístico de una carta literaria conservada en el manuscrito Ebr-Arb I 4575 de la colección Firkovich. Su autor parece mantener una estrecha relación con el destinatario, quizá se trate de su kātib o secretario personal; en todo caso el autor de esta carta es la persona que se encarga de conseguirle copias de obras y prepararle otro tipo de materiales. La carta muestra claramente la atmósfera cultural de la época y sus categorías estéticas y sobre todo, lo difícil que era conseguir una copia fidedigna de un diván poético andalusí.

Palabras Clave: Guenizá; prosa rimada; Alandalús; judeo-árabe.

A Literary Letter from the Cairo Genizah in Judeo-Arabic.- This paper includes the edition, translation, study of the contents and the linguistic analysis of a literary letter preserved in the manuscript Ebr-Arab I4575 of the Firkovich collection. The author seems to keep a close relationship with the addressee; he might be his kâtib or personal secretary. In any case the author of this letter is the person in charge of provide the addressee with copies of books and prepare other materials. The letter clearly shows the cultural atmosphere and the aesthetic categories of the time and above all, how hard it was to get a reliable copy of an Andalusi divan.

KeYwords: Genizah; Rhymed Prose; Alandalus; Judeo-Arabic.

*Este trabajo se encuadra dentro del Proyecto de Investigación «Recuperación y estudio del legado lingüístico judeo-árabe de al-Andalus» (ref. núm. FFI2014-51818-P). Queremos expresar nuestro más profundo agradecimiento a las personas que de manera anónima y desinteresada evaluaron este artículo, pues sus anotaciones han enriquecido muchísimo la versión final de este trabajo.

"*** pdelgado@ugr.es, landsyria@hotmail.com 
Las cartas de carácter personal conservadas en la Guenizá de El Cairo son una de las mejores maneras de acercarse a la sociedad medieval en general y a la cultura judía de la época en particular ${ }^{1}$. En la mayoría de las ocasiones estamos tratando con documentos privados de muy difícil interpretación, cuyos párrafos resultan casi inconexos o crípticos, quizá, como en el caso de la presente, por ser respuestas a otras misivas previas que no conocemos. A diferencia de otros documentos de carácter epistolar de la Guenizá ${ }^{2}$ la carta aquí presentada tiene el valor de ser inédita y de estar introducida en prosa rimada. Sus contenidos nos sugieren que podría tratarse de una carta redactada en Alandalús, a finales del siglo XI o a lo largo del XII. Su autor parece mantener una estrecha relación con el destinatario al que denomina siempre mawlà 'señor', quizá se trate de su kātib o secretario personal; en todo caso el autor de esta carta es la persona que se encarga de conseguirle copias manuscritas de libros que incluso edita y de prepararle otro tipo de materiales. La carta tiene el valor de mostrarnos cómo era la atmósfera cultural de la época y sus categorías estéticas y sobre todo, lo difícil que era conseguir una copia fidedigna de un diván poético andalusí.

El documento que presentamos se compone de un total de 47 líneas dispuestas a lo largo de un folio y medio (2 líneas - 19 líneas - 17 líneas - 9 líneas) y se conserva en el manuscrito Ebr-Arb I 4575 de la colección Firkovich. En realidad el manuscrito se compone de 30 folios y aloja, en este orden:

\footnotetext{
${ }^{1}$ Para el caso del Mediterráneo, véanse referencias clásicas como Jacob MANN, Texts and Studies in Jewish History and Literature (Cincinnati 1931-1935); Shelomo D. GortTein, A Mediterranean Society: the Jewish Communities of the Arab World as Portrayed in the Documents of the Cairo Geniza (Berkeley 1967-1993). Para otros casos véase, por ejemplo, Norman Golb y Omeljan PritsaK, Khazarian Hebrew Documents of the Tenth Century (Ithaca 1982) y más recientemente S. D. GoITTEIN y Mordechai Akiva Friedman (with the assistance of Amir Ashur), Halfon The Traveling Merchant Scholar: Cairo Geniza Documents (Jerusalem 2013 [en hebreo]).

${ }^{2}$ Normalmente son cartas redactadas por motivos comerciales y de ellas se pueden desprender otros tipo de datos de distinta naturaleza, véanse, entre otros, los casos de Amir Ashur y Ben Outhwaite, «Between Egypt and Yemen in the Cairo Genizah», Journal of Islamic Manuscripts 5 (2014) págs. 198-219; M. a Ángeles Gallego y Amira K. Benison, «Jewish Trading in Fes on the Eve of the Almohad Conquest», Miscelánea de Estudios Árabes y Hebraicos. Sección Hebreo 57 (2008) págs. 33-51.
} 
1. Copia completa del Kitāb al-af'āl dâwāt al-mițlayn 'Libro de los verbos con (letras) geminadas' del célebre gramático cordobés del siglo X, Abū Zakariyā' Yahyyà ibn Dāwūd, mas conocido como Ḥayyūğ ${ }^{3}$; esta copia es de suma importancia, tanto por su antigüedad, fechada en el año 1120, siendo la copia completa más antigua conocida, como por afirmar en su portada que es copia del autógrafo: mimmā nasah linafsi-hi. Se presenta como la cuarta parte de su pareja inseparable Kitāb al-af'āl $\underline{d} a w \bar{a} t$ hurüf al-līn 'Libro de los verbos con letras débiles', si bien esta parte no se conserva. Respecto a la obra autógrafa de Ḥayyūğ, los autores de la colección Rasā'il al-rifāq 'Epístolas de los compañeros' afirman en la segunda parte de la primera epístola contra el gramático Ibn Ğanāh wa- 'alà anna 'indanā fì l-nusha allatì bi-hatț yadi-hi nuho 'eden... 'Sin embargo lo que nosotros encontramos en su copia autógrafa ¡descanse en paz!.... ${ }^{4}$. El autor de estas epístolas no es otro que Samuel ibn Nagrela (Córdoba 995 - Granada 1056), al que la tradición le atribuye el privilegio de ser discípulo directo y personal de Ḥayyūğ ${ }^{5}$, por lo que ciertamente podría tener en su poder el original y el texto conservado en este manuscrito ser copia de ese original ${ }^{6}$.

2. El poema me'el 'elom yubal šalom 'De Dios del Universo llega un saludo' del célebre poeta granadino del siglo XI Abū Hārūn Mošeh ibn

\footnotetext{
${ }^{3}$ Esta obra fue editada originalmente por Morris JASTROW, The Weak and Geminative Verbs in Hebrew by Abû Zakariyyâ Yahyâ ibn Dâwud of Fez, Known as Hayyû̄g; the Arabic Text Now Published for the First Time (Leiden 1897); existe una traducción al español por José Martínez Delgado, Yahyá ibn Dāwūd, El libro de Hayyūŷ: versión original árabe del siglo $X$ (Granada 2004).

${ }^{4}$ En el original ועלי אן ענדנא פי אלנסכה אלתי בכט ידה נע (Firk II 1239: 6r:1-2). Este fragmento fue publicado en grafía árabe por Joseph y Hartwig Derenbourg, Opuscules et traites d'Abou'l= Walid Merwan Ibn Djanah de Cordoue. Texte arabe publié avec une traduction française (Paris 1880) pág. LXIII.

${ }^{5}$ Así lo afirma Solomon Ibn Parḥon en su Maḥberet ha- 'arukh, edition by Solomon G. STERn (Pressburg 1844) pág. XXII.

${ }^{6}$ Siguiendo el rastro a esta copia autógrafa, Abraham ibn Daud (1110-1180), afirma en su Sefer ha-Qabbalah que Yișhaq Ibn Balya (1035-1094) intentó reunir de nuevo la biblioteca del Nagid en Sevilla, tras la matanza de judíos acaecida en Granada en el año 1066 (véase Gerson D. CoHEn, A Critical Edition with a Translation and Notes of the Book of Tradition (Sefer ha-qabbalah) (Philadelphia 1967). Para la masacre de judíos en Granada véase el testimonio de Moshe ibn 'Ezra, Kitāb al-muḥạ̄ara wa-l-mud̄ākara, edición de Montserrat Abumalham (Madrid 1986) fol. 35.
} 
'Ezra (ca. 1060 - ca. 1139) ${ }^{7}$, introducido de forma anónima mediante la fórmula li-ba 'ḍihim 'de uno de ellos'. Se trata del poema que introduce la carta hebrea dirigida a Yo’šiya ben Bazzāz y que Brody data entre los años 1091 y $1095^{\circ}$. La lectura del poema en esta copia presenta algunas variantes respecto a la edición de Brody, si bien parece pertenecer a la familia representada por los manuscritos Oxford y Kaufman ${ }^{9}$.

3. Nuestra carta, seguida de unos breves apuntes sobre licencias métricas tomadas del Kitāb al-luma del gramático cordobés del siglo XI Abū 1-Walīd Marwān ibn Ğanāh (Córdoba, ca. 990 - Zaragoza, ca. 1050) ${ }^{10}$; podría dar la impresión, por tanto, que el poema de Mošeh ibn 'Ezra se empleó para introducir la carta que nos ocupa, pues esa era la función original del poema, introducir una carta, en hebreo, dirigida a un importante personaje.

4. El último texto contenido en este manuscrito es una copia del poema que Hāy ben Šěrira (939-1038), Gaón de Pumbedita, envió a rabí Abraham ben 'Ața, nagid de Kairuán', en la actual Túnez. Es copia de otra mano. La edición más completa de esta carta es la elaborada por Brody ${ }^{12}$.

Hay que tener en cuenta que, según se desprende de los contenidos, la carta está incompleta. El autor afirma que previamente ha preparado una

\footnotetext{
${ }^{7}$ Metro: mutadārik. Poema 192, Heinrich BRody (ed.), Shire ha-ḥol (Berlin 19341977) vol. I, pág. 191.

${ }^{8}$ Carta 263 (BRody, Shire ha-ḥol, vol. II, pág. 360).

${ }^{9}$ A diferencia de estos, esta versión es completa, incluyendo los versos 10 y 15 . Al igual que las otras dos copias, omite los nombres propios, si bien en esta versión se opta por

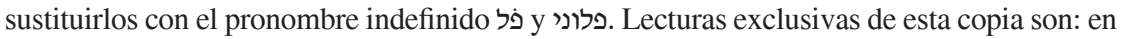
el v. 14 אותה por ועליה por en el v. 15 ועליהם (Brody, Shire ha-hol, vol. I, pág. 191).

${ }^{10}$ Editado originalmente por Joseph Derenbourg, Livre des parterres fleuris; grammaire hébraïque en arabe d'Abou 'l-Walid Merwan ibn Djanah de Cordoue (Paris 1886).

${ }^{11}$ También Isaac ibn Khalfun (s. X) de Córdoba le dedica un poema a este importante personaje, edición de Aharon Mirski, Isaac ibn Khalfun. Poems (Jerusalem 1961 [en hebreo]) págs. 63-66. Traducido por María José Cano, Yiṣhqa ibn Jalfun poeta cortesano cordobés (Córdoba 1988) págs. 70-72.

${ }^{12}$ Hayim Brody, «Religious and Laudatory Poems of R. Hayya Gaon», Studies of the Research Institute for Hebrew Poetry 3 (1936 [en hebreo]) págs. 28-31, basada en el manuscrito de la colección Taylor Schechter custodiado en la Biblioteca Universitaria de Cambridge (núm. T-S 8k 14 5).
} 
lista de obras que se dan por perdidas y que adjunta al final por escrito. Dicha lista no se conserva en esta versión. En este contexto, en el que encontramos la carta, precedida por un tratado de gramática de consulta obligada y que afirma ser copia del autógrafo del autor, y flanqueada por poemas hebreos, no queda otra que preguntarse qué hace esta carta incompleta aquí. Sólo se nos ocurren dos posibilidades: o bien el propietario del manuscrito era el autor de la carta, o quizá un familiar, y quiso conservar una copia del corpus principal de la misiva; o bien se trata, junto con los dos poemas, de muestras de ejercicios retóricos en los que inspirarse a la hora de redactar tanto este tipo de misivas como poemas hebreos $^{13}$. En todo caso, el análisis lingüístico pone de manifiesto una serie de posibles erratas, recogidas en nota en la edición, que parecen apuntar al hecho de que se trata de una copia y no del documento original.

\section{Estructura de la CARTA y ANÁLISIS DE SUS CONTENIDOS}

La estructura de los contenidos de la carta es la siguiente:

1. Agradecimiento en prosa rimada ( $\mathrm{sağ}^{\circ}$ ) al destinatario por haber enviado un escrito [29v:18-30r:13].

No nos resulta del todo claro si el agradecimiento del autor se refiere a la carta a la que responde o si esta venía acompañada además de una especie de diccionario biográfico de sabios judíos ( $m u$ 'ğam al-mu'allifin) tan del gusto en la época ${ }^{14}$. En todo caso, a partir de las alabanzas del destinatario se entiende que este escrito contenía gran cantidad de poemas: 'cuán insólitos son sus segundos hemistiquios y los primeros y cuán maravillosos sus adornos y selecciones pues es sencilla en su comienzo y en su trama' [30r:11-13]. Toda esta primera sección de agradecimiento está redactada en prosa rimada ( $\left.s a g^{`}\right)$ y está cargada de figuras retóricas.

\footnotetext{
${ }^{13}$ Estas recopilaciones de composiciones estilísticas y ensayos en hebreo para su uso como manuales retóricos fueron muy frecuentes y llegaron a alcanzar el nivel de antologías en época mucho más tardía, exactamente durante el Renacimiento italiano, véase sobre este punto Yacov BoKsenBorm, Igěrot Yěhude Italya (Tel Aviv 1994).

${ }^{14}$ El único del que tenemos referencia explícita en Alandalús es Fậa’’il ahl al-ādāb $w a-l-a h s \bar{a} b$ 'Las excelencias de los literatos y personajes notables' de Mošeh ibn 'Ezra, que hoy se da por perdida y que conocemos su existencia gracias al propio Mošeh ibn 'Ezra, que la menciona en su Kitāb al-muḥạ̄̂ra wa-l-mud̄ākara.
} 
De hecho, en toda esta primera sección, y la siguiente, el autor ha hecho rimar prácticamente todo el discurso, por ejemplo al-šayh al-ğalīl - al-habr al-nabīl [1-2: 'ilustre maestro - noble sabio']; salaf karìm - šaraf șamìm [30r:2 'ilustre ascendencia - auténtica nobleza']; adāma allahu 'uluwwahu - wa-kabata 'aduwwa-hu [2: 'Dios conserve su grandeza - y humille a sus enemigos']; wa-națaqa bi-lisāni su'dad așil - wa-ahbara 'an mağ din fi ğumlat ${ }^{\text {in }}$ wa-tafșīl [30r:2-3 'se expresa con lengua de señorío auténtico - y narra la gloria de manera conjunta y pormenorizada]; fa-anāra 'ayn̄̄ ‘iyāna-hu - wa-ğalà șadà șadrī bayāna-hu [30r:3-4 'verla ha iluminado mis ojos - y su elocuencia ha eliminado la herrumbre de mi pecho'], etc.

Además, en esta sección se emplea con relativa frecuencia la antítesis $(t i b \bar{a} q)$, por ejemplo adāma - wa-kabata [2: 'conserve - y humille']; a '̌̆āza-hu șudūra-hu [30r:12 'sus segundos hemistiquios y los primeros']; mabdā-hi - masdā-hi [30r:13 su comienzo - su trama] ${ }^{15}$; layālì-hi wa-ayyāmi-hi [30r:8 'sus noches y sus días']; nawr - zulam [30r:8 'luz - oscuridad'].

Destaca sobre todas las figuras el uso de ğinās nāqiș en 'uluwwa-hu y 'aduwwa- $h u$ [29v:2 'su grandeza' y 'sus enemigos']; en 'iуānu- $h u$ y bayānu-hu [30r:4 'verla' y 'su elocuencia']; en wa-nawr ${ }^{a n}$ y wa-nüra [30r:7-8 'y una flor' y 'y una luz']; hawa $-h u$ y țawā-hu [30r:9 'su contenido' y 'lo que abarca']; bi-mabdā-hi y bi-masdā-hi [30r:13 'en su comienzo' y 'en su trama' $]^{16}$, etc.

Junto a este uso, también se emplea la metáfora makniyyah o prosopo-

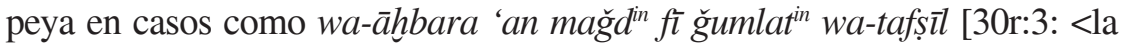
carta> 'narra la gloria de manera conjunta y pormenorizada'] y en wa-qumtu lahu 'alà qadam at-taqdīs wa-l-i' 'zām [30r:5-6: 'la he recibido <la carta> en persona con honores y he adoptado una actitud de veneración y reverencia'].

2. Un breve pasaje de transición para abandonar la prosa rimada (sağ “) [30r:13-17].

La breve transición (tahalluṣ) para abandonar la prosa rimada (sağ') también está plagada de figuras retóricas. Hay ğinās nāqiș en asdà y ahdà

\footnotetext{
${ }^{15}$ Sobre estas formas véase más adelante el apartado dedicado al estudio lingüístico.

${ }^{16}$ Sobre estas formas véase más adelante el apartado dedicado al estudio lingüístico.
} 
[30r:13-14 'gracia' y 'longanimidad']; en sa 'ādati-hi y siyādati-hi [30r:16 'su dicha' y 'su poderío']. También emplea la prosopopeya en šukr arriyāẹ li-l-amțār [30r:14: 'el agradecimiento de los jardines a la lluvia'] y en fa-lā mallat al-aqdār kuftan (léase kāfilat ${ }^{a n}$ ) [30r:15-16: "el Destino no ha cesado de garantizar']. Destaca, finalmente, el doble tašbīh o comparación expresada por medio de prosa rimada (sağ') en šukrī lahuma šukr ar-riyā d li-l-amțār wa-našrī bihuma našr an-nasīm fì l-ashāar [30r:14-15: 'agradezco a ambos con el agradecimiento de los jardines a la lluvia y me reanimo con ambos como se reanima la brisa en las madrugadas'].

\section{Compromiso con el destinatario a ordenar una lista [30r:17-30v:2]}

Tras esta transición, se llega a lo que consideramos el núcleo de la carta: el compromiso por parte del autor con el destinatario a ordenar una lista de existencias $\left(l \bar{a}^{\prime} i h a\right)$ y de mercancías perdidas (qawăti $\left.i^{\circ}\right)$, rogándole que disculpe los errores que esta pueda incluir. Este pasaje alude además a secciones que precedían y seguían a la carta que hoy no se conserva: 'ya he aclarado antes y he hecho saber previamente la preparación de la lista de existencias y de mercancías perdidas claramente y por escrito, [al] ${ }^{[30 \mathrm{v}]}$ final'. En cuanto a la lista de existencias $(l \bar{a}$ 'ih $h$ ) y de mercancías perdidas (qawăti $i^{\circ}$ ), a tenor del contenido general de la carta, es muy probable que se trate de una lista de obras que ya no puede conseguirle de ninguna de las maneras.

4. Alusión a un ilustre personaje al que ambos han conocido personalmente [30v:2-7].

El siguiente pasaje contiene una alusión a un tal rabbi Abūn, representante de una generación o grupo de personas ilustres, al que ambos, autor y destinatario, han conocido personalmente. El destinatario parece haber incluido algunas notas biográficas sobre él o bien en la misma carta a la que se está respondiendo aquí o en un libro que le envía al autor de la carta; si bien, el autor de nuestra carta ha de reconocerle con cierta decepción que "no añadió más de lo que yo sabía y conocía por mi experiencia personal'. Cierra esta sección excusando al destinatario recurriendo al uso de ğinās nāqiș en bi-țūl țawli-hi [30v:7 'la talla de sus buenas acciones']. No ha sido posible identificar aún a este Abūn, aunque si entende- 
mos que la carta es andalusí, por su contexto y lengua, y posterior al año 1055 (más adelante se cita a Samuel ibn Nagrela con la bendición para los fallecidos), podría tratarse quizá de Abūn de Granada o de Abūn ben Šřrarah ${ }^{17}$. Al primero le dedicó Mošeh ibn 'Ezra numerosos versos, sobre todo elegías ${ }^{18}$, ya que se conocieron desde su juventud, incluso dice de él al quejarse de su destierro al final de sus días a R. Hanan'el ben Yěšua “ ${ }^{19}$ :

la más escogida de las criaturas / jefe de los llamados / admirable por sus virtudes / único en sus obras / nuestro maestro Abūn ¡viva eternamente! / ¡su dicha no cese! / él es para mí una fortaleza / para los momentos de angustia / y un torreón / cuando se crece el dolor / y una puerta y una muralla / que espanta la confusión / y un sol de justicia / en la tiniebla de la aflicción / desde lejos se aspiran sus aromas / y hasta en los confines de la tierra se huele su incienso / de boca de sus libros / escucho sus palabras / y ante sus escritos / veo su amor / de su lugar de residencia / me llegan sus obras / corren a calmar mi rostro / en mi cama por la noche / y clamo en mis momentos de aflicción / desde tierras remotas a mi consejero.

En cuanto a Abūn ben Šĕrarah, se trata de un poeta y la escasa información que tenemos sobre él también nos llega por medio de Mošeh ibn 'Ezra que en su Kitāb al-muhạậra wa-l-mudākara lo sitúa en la época de mayor esplendor, durante el visirato de Yěhosef ibn Nagrela (asesinado en 1066),

\footnotetext{
${ }^{17}$ No está del todo claro que estos dos autores no sean en realidad la misma persona. El nombre Abūn es relativamente frecuente, sobre todo en Alandalús donde aparece ya registrado en una lápida funeraria del siglo IX hallada recientemente en Córdoba (Isabel larrea Castillo y Enrique Hiedra Rodríguez, «La lápida hebrea de época emiral del Zumbacón. Apuntes sobre arqueología funeraria judía en Córdoba», Anejo de Anales de Arqueología Cordobesa 2 [2009-2010] págs. 327-342) y en el siglo X como nombre de uno de los primeros poetas hebreos de Córdoba, de la generación de Měnahem ben Saruq y Dunaš ben Labraț, según se desprende de unos versos de Ibn Gabirol -véase la edición de Hayim Brody y Jefim Schirmann, Solomon ibn Gabirol. Secular Poems (Jerusalem 1974 [en hebreo]) págs. 65-66, poema 115, específicamente el verso 8-y de la cita de Yěhudah al-Harizi en su Sefer Tahkěmoni -véase la edición de Joseph Yанацом y Naoya Katsumata, Tahkemoni or the tales of Heman the Ezrahite (Jerusalem 2010 [en hebreo]) pág. 109, lín. 165-. Sobre este poeta véase Jefim SchIRMAnN, Tolëdot ha-širah ha-'ibrit bi-Sfarad hamuslemit, ed. Ezra FleISCHER (Jerusalem 1995) pág. 128.

${ }^{18}$ Véanse los poemas núm. 8, 9, 71, 74, 88, 205, 224 y 235 de BRody, Shire ha-ḥol, vol. I.

${ }^{19}$ Carta 262 (BRody, Shire ha-ḥol, vol. I, págs. 289, líns. 85-91).
} 
justo antes de mencionar al famoso comentarista Mošeh ibn Ǧiqațila. Ibn 'Ezra ubica a Abūn ben Šĕrarah primero en Lucena y más tarde en Sevilla ${ }^{20}$. Finalmente, se conoce un céjel en hebreo clásico, en cuyo acróstico puede leerse el nombre Abūn, datado alrededor del año 1110 y que podría pertenecer a alguno de estos dos personajes o bien ser de otro distinto a ellos ${ }^{21}$. Con todo, no podemos afirmar con certeza si este Abūn es uno de estos personajes ilustres y siquiera si era andalusí. En todo caso, el autor de la carta no escatima en elogios hacia su persona calificándolo como 'esplendor de la época y la flor y nata de los amigos' y considerándolo a título más personal 'mi pilar superior y lote del botín de la humanidad'.

5. Estado de la copia de las colecciones Ben Mišle y Ben Qohelet de Samuel ibn Nagrela solicitada al autor de la carta por el destinatario [30v:8-31r:1].

El destinatario ha solicitado del autor una copia completa de las colecciones de poemas Ben Mišle y Ben Qohelet de Samuel ibn Nagrela ${ }^{22}$. El autor confiesa que lo ha intentado todo pero que sólo tiene una copia incompleta y que va a hacer todo lo posible por completarla. Resulta curioso que reconozca tener acceso a copias autógrafas, cuando esta compilación fue realizada por Yěhosef ibn Nagrela, hijo del autor, en el año 1044 cuando contaba, según él mismo, con ocho años y seis meses de edad ${ }^{23}$. El propietario de estas copias autógrafas se niega a venderlas, a pesar de que el autor, tras regatear, le ha ofrecido la generosa cantidad de dos dinares (unos 8 gramos de oro). El destinatario debe conformarse con la copia incompleta que el autor le facilitó previamente. Es interesante que siendo una copia autorizada (tawkîl) esté incompleta, dando

\footnotetext{
${ }^{20}$ Авимalham (ed.), Kitāb al-muhāạdara wa-l-mudāakara, fol. 36.

${ }^{21}$ Editado y datado por Jefim SchiRmann, Ha-širah ha-'ibrit bi-Sfarad u-bĕ-Provence (Jerusalem 1954-1956) vol. I, págs. 341-342.

${ }^{22}$ Los casi dos mil poemas que hoy se conocen de este autor se agrupan en tres grandes colecciones que conforman su diván: Ben Těhillim, Ben Mišle y Ben Qohelet; del primero existe una nueva edición en dos volúmenes (bilingües) por Ángel SÁENZ-BADILlos y Judith Targarona, Šĕmu'el ha-Nagid. Poemas. I Desde el campo de Batalla (Córdoba 1988) y Šému'el ha-Nagid. Poemas. II En la Corte de Granada (Córdoba 1998). La mejor edición conocida hasta el momento de todo el diván es la realizada por Dov YARDEN, Diwan Šému'el ha-Nagid (Jerusalem 1966-1992).

${ }^{23}$ Sáenz-Badillos y Targarona, Šěmu'el ha-Nagid. Poemas. II, pág. 282.
} 
testimonio de la corrupción en el proceso de transmisión ya en la época. Dado que esta copia, además, no está cuidada desde un punto de vista estético, el autor de la carta se compromete a elaborar una especie de edición crítica del texto mucho más cuidada en todos los aspectos, tal y como le ha solicitado y autorizado el destinatario.

De nuevo, encontramos el uso de ǧinās nāqiṣ en fā'iqah rā'iqah [30v:10 'muchas y selectas']; y en halqu-hu y hulqu-hu [30v:15 'su obra' y 'su naturaleza'].

6. El autor se niega a enviarle al destinatario los pocos versos que ha compuesto y se despide [31r:1-9].

El autor se niega a enviarle al destinatario los pocos versos que ha compuesto, que según él no parecen ser más de cinco, pues afirma que son 'menos que los dedos de mi mano', y no la considera digna de ser recitada en público y mucho menos memorizada. Dado que según él no alcanza la forma 'de tejido nuevo de sutil textura' no va a satisfacer su solicitud. Es curioso que en este pasaje vuelva a emplear figurar retóricas como el ǧinās nāqiṣ en yulhaz y yuḥfaz [31r:3 'notada' y 'memorizada']. Tras esta negativa, el autor se despide del destinatario.

\section{AnÁlisis LingÜístico}

En lo que se refiere a la ortografía y fonética del texto, no se pueden sacar conclusiones sobre el vocalismo dada la naturaleza exclusivamente consonántica del texto, tan sólo en una ocasión aparece damma en כפُלא (30r:16 kuflan), si bien se trata de una clara errata ortográfica y léase $k \bar{a} f i l a t^{a n}$, en concordancia morfosintáctica con el siguiente hạarisat ${ }^{a n}$, siendo ambos acusativos adverbiales $(h \bar{a} l)$. En todo caso, el consonantismo sigue las pautas de la ortografía arabizada del periodo clásico (siglos $\mathrm{X}-\mathrm{XV})^{24}$. Así lo refleja además el uso las semiconsonantes como soporte gráfico de hamza, por ejemplo פאיקה ראיקה (30v:10 fā'iqah rā'iqah) o סודד (30r:2 su’dad ${ }^{\text {in }}$.

\footnotetext{
${ }^{24} \mathrm{M} \cdot{ }^{\mathrm{a}}$ Ángeles Gallego, El judeo-árabe medieval; Edición, traducción y estudio lingüístico del Kitāb al-taswi’a de Yonah ibn Ğanāḥ (Bern 2006) págs. 18-24.
} 
El único signo auxiliar de lectura empleado en una ocasión es šadda en עלו̈ (29:19 'uluwwa-hu). Aunque lo normal es que no se refleje, por ejemplo דרא (30r:7 durr ${ }^{a n}$ ), también puede darse una geminación gráfica, por ejemplo el caso de waw en ותצווע (30r:8 wa-tadawwa 'a) minación puede darse en otras consonantes, por ejemplo, ממ[ללת (30r:15 mallat) y פאעז (30r:10 fa-a'azzi). Por el contrario, echamos en falta una alif en la voz עדרי [31r:6 'id

Destaca la forma nominal במסדיה (30r:13 bi-masdā-hi 'su trama'). Puede explicarse desde el árabe medio, donde con normalidad se trata $m a b d a '$ como si fuera $\{$ bdw/y $\}$ y, para fabricar la rima, se ha recurrido al raro mașdar mīmī del verbo asdă ${ }^{26}$.

Formaciones típicas del árabe andalusí son el uso de la forma VI (30r:10 wa-taḥāsasat) cuando lo esperado era la v; y lo mismo ocurre en פ פ בסס עדרי / fi bass 'id ârrī donde bass 'besar' es un andalusismo típico, en este caso 'besar mi mejilla' es una metáfora por 'me disculpará'.

Por lo que se refiere a las partículas, encontramos פלא פצצת / fa-la ', fadadtu donde se esperaba fa-lammā' fadadtu 'cuando rompí', un claro caso de lapsus calami.

No se ha detectado la forma de admiración muy clásica y hasta un poco rebuscada af'il bi- en פאעז בה... ואנפס בה (30r:10-11 fa-a'azzi bih... wa'anfis bih 'se enorgullece... se considera precioso').

\footnotetext{
${ }^{25}$ Joshua Blau, A Grammar of Mediaeval Judaeo-Arabic (2 ${ }^{\text {a }}$ ed., Jerusalem 1980 [en hebreo]) §29.1, pág. 48.

${ }^{26}$ También se podría suponer lo contrario, que ha derivado ambas voces de una raíz hamzada, leyendo bi-mabdā'i-hi y *bi-masdā'i-hi, aunque nos inclinamos por la primera opción.
} 
3. Edición de Firkovich Ebr-Arb I 4575 (fols. 29v:18 - 31r:9) ${ }^{27}$

\author{
אלול אן כתאב מולאי אלשיך אלגליל אלחבר \\ אלנביל אדאם אללה עלוّה וכבת עדוה ורדני מסתוליא
}

[30r]

עלי סלף כרים ושרף צמים ונטק בלסאן סודד גמות גמנת גונית

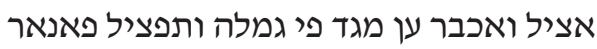

עיני עיאנה וגלי צדא צדרי ביאנה פתליקיתה

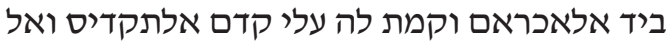

אעטאם פלא ${ }^{28}$

ראית דרא ראק פי נטאמה ונורא תפתח ען כמאמה

ונורא כשף טללם ליאליה ואיאמה ותצווע אלקטר

טיבא במא חואה ופאח אלאפק נשרא במא טואה ומאלת אלנפוס אליה ותחאססת אלחואס עליה פאעזז

בה מן כתאב ואנפס בה מן כטאב מא אגרב

אעגאזה וצדורה ואעגב נבדה ושדורה פ[הו סהלא]

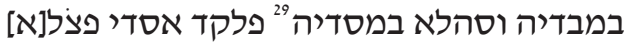

ואהדי טולא שכרי להמא שכר אלריאץ ללאמ[טאר]

ונשרי בהמא נשר אלנסיס פי אלאסחאר פלא [מ]ללת

אלאקדאר כפُלא

מנקאדה לאראדתה בעזתה תעאלי וקותה וקד

בינת פי מא קדמת וערפת פי מא אסלפת מן אעדאד

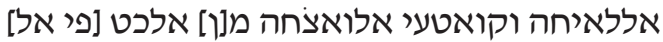

\footnotetext{
${ }^{27}$ Hemos tenido acceso al texto a través de la copia microfilmada del Instituto de microfilmes de la Biblioteca Nacional de Israel sito en la Universidad Hebrea de Jerusalén, número F58395. Queremos expresar aquí nuestro más profundo agradecimiento a todo el personal de dicho Instituto.

${ }^{28}$ Léase פלמא.

${ }^{29}$ Esta forma parece un neologismo del autor que para fabricar la rima utiliza un raro mașdar mīmī del verbo asdà.

${ }^{30}$ Se trata de una clara errata ortográfica y léase $k \bar{a} f i l a t^{a n}$, en concordancia morfosintáctica con el siguiente $h \bar{a} r i s a t^{a n}$, siendo ambos acusativos adverbiales ( $\left.h \bar{a} l\right)$.
} 
רנהאיה ופצלה יקבל אלעדר ויסבל עלי מא תצמנה

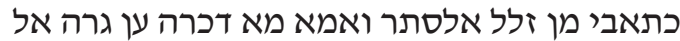

זמאן וצפוה אלאכואן ר אבון עמאדי אלאעלי וחצי

מן צפיה אלורי אחסן אללה דכראה ואצל פי עקבאה

וגעלוה פדאה פמא זאד עלי מא עהדתה מנה

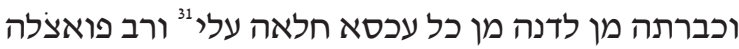

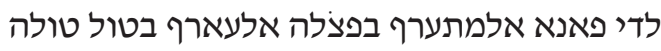

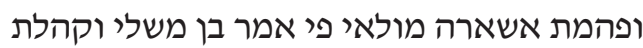

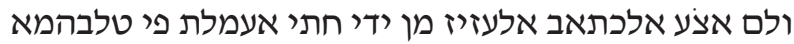

גאיה גהדי פ\}נ\{טטרת גִאם

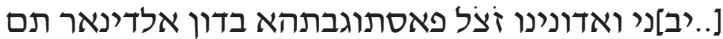

[א]בי צאחבהא פצאעפת לה קימה פמא אנקאד גמלה פלם תכן לי חילה וכאנת ענדי אלנסכה אלואצלה אלי מואלי

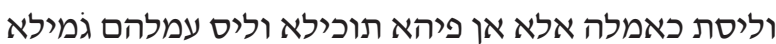

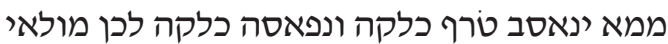

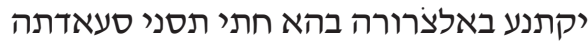

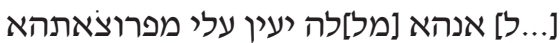

מ31r] מא אלתמסה מולאי מן שערי פהו אקל מן ידי פכיף אן ירוי ואן ילחט פכיף אן יחפט ומא אקרץ ואלעלים

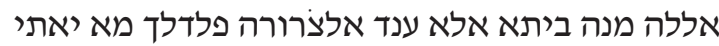

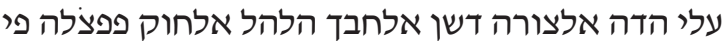
בסס עדרי ותאול אלכיר פי אמרי ומואד אלסעאדה אלי מולאי מנסאבה וופוד אלבשאיר עלי סאדתה

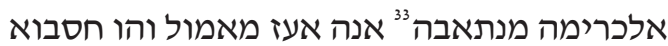

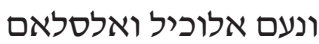

\footnotetext{
${ }^{31}$ Léase 'aksah hallā-hā 'alayya.

${ }^{32}$ No sabemos con seguridad lo que quiere decir ğ̀im - alif - mìm; parece una abreviatura para «manuscrito» o algo parecido, pero no lo reconocemos ni en árabe ni en hebreo.

${ }^{33}$ En el original מנתאכה.
} 


\section{TRADUCCIÓN}

${ }^{[29 v: 18]} \mathrm{La}$ carta de mi señor, ilustre maestro, noble sabio, Dios conserve su grandeza y humille a sus enemigos, que me ha llegado colmada ${ }^{[30 r]}$ con la generosidad de la gracia de mi señor, el más hermoso entre los hermosos y longánime, confirma la ilustre ascendencia y auténtica nobleza, expresándose con lengua de señorío auténtico y narrando la gloria de manera conjunta y pormenorizada. Verla ha iluminado mis ojos y su elocuencia ha eliminado la herrumbre de mi pecho. La he recibido en persona con honores y he adoptado una actitud de veneración y reverencia. Cuando rompí su lacre y corrí su velo, hallé perlas brillando en su engarce, flores abriéndose en su cáliz, luz que quita la oscuridad de su noche y sus días, desprende gotas perfumadas de su contenido y el horizonte exhala el aroma de lo que abarca; las almas se sienten atraídas hacia ella y los sentidos se aguzan en su búsqueda. Qué excelente carta y qué precioso escrito. Cuán insólitos son sus segundos hemistiquios y los primeros y cuán maravillosos sus adornos y selecciones pues es sencilla en su comienzo y en su trama. Ya ha prestado gracia y ha ofrecido longanimidad, por lo que agradezco a ambos con el agradecimiento de los jardines a la lluvia y me reanimo con ambos como se reanima la brisa en las madrugadas. Que el Destino no cese de garantizar su dicha, velando por su poderío, sometido a su voluntad por el poder y la fuerza del Altísimo.

Ya he aclarado antes y he hecho saber previamente la preparación de la lista de existencias y de mercancías perdidas claramente y por escrito, [al] ${ }^{[30 v]}$ final, y su gracia aceptará la disculpa y disimulará los errores que contiene mi escrito.

Cuando menciona a Rabbi Abūn, esplendor de la época y la flor y nata de los amigos, mi pilar superior y lote del botín de la humanidad, Dios beneficie su mención y arraigue en su descendencia y den su vida por la suya, no añadió más de lo que yo sabía y conocía por mi experiencia personal, contrariedad que él me endulzó, y todas sus virtudes, y yo reconozco su gracia, conozco la talla de sus buenas acciones.

He captado la alusión de mi señor en lo que se refiere a Ben Mišle y Qohelet y no he apartado de mi presencia la ilustre carta hasta el colmo de lo imposible por conseguir ambos. He revisado muchas y selectas copias autógrafas $[\ldots]$ de nuestro señor, el justo descanse en paz; quise 
conseguirlas por menos de un dinar pero su dueño lo rechazó y aunque le doblé el precio no aceptó bajo ninguna circunstancia. No me ha quedado otra opción y tengo la copia que se envió a mi señor que está incompleta aunque tiene una autorización y no es una copia cuidada tal y como corresponde al valor de esta obra y al estatus de su naturaleza. Sin embargo, mi señor se contentará con ella por necesidad hasta que su excelencia tenga la posibilidad $[\ldots]^{34}$ ayude en sus exigencias ${ }^{[31 r]}$ para yo cumplirlas y proceder con libertad, totalmente complacido en ellas.

En cuanto a mi poesía, que me ha solicitado mi señor, es menor que los dedos de mi mano. Cómo va a ser recitada de memoria y notada entre el público; cómo va a ser memorizada si yo no recito, y bien lo sabe Dios, ni un verso mío a no ser por obligación y dado que no aparece a la manera de tejido nuevo de sutil textura, su gracia me disculpará ${ }^{35}$, prolongará la bondad para conmigo y que no cesen los motivos de felicidad para mi señor y le lleguen continuamente buenas nuevas a su querida excelencia pues Él es la más gloriosa esperanza y Él nos basta y es el mejor procurador. Vale.

Recibido: $15 / 09 / 2015$

Aceptado: 15/10/2015

\footnotetext{
${ }^{34}$ La falta de una palabra impide asegurar la inteligencia de esta frase.

${ }^{35}$ Literalmente bass 'id̄ārī ‘besar mi mejilla', se trata de una metáfora por 'disculpar'.
} 